\title{
HUBUNGAN STATUS SOSIAL EKONOMI ORANGTUA DENGAN MOTIVASI BELAJAR PADA MAHASISWA ANGKATAN 2013 FAKULTAS KEDOKTERAN UNIVERSITAS SAM RATULANGI
}

\author{
${ }^{1}$ Caroline R.M. Karouw \\ ${ }^{2}$ Henry Opod \\ ${ }^{2}$ Jehosua S.V. Sinolungan
}

\author{
${ }^{1}$ Kandidat Skripsi Fakultas Kedokteran Universitas Sam Ratulangi Manado \\ ${ }^{2}$ Bagian Psikologi Fakultas Kedokteran Universitas Sam Ratulangi Manado \\ Email: carolinerosalia@ymail.com
}

\begin{abstract}
Learning is a process that can not be separated from human life. Psychic impulse to learn is the motivation to learn. In the learning process, parents are among the factors that have a role. This study aims to determine the relationship of socio-economic status of parents with students' learning motivation. Data were collected through questionnaires. The results showed there was no correlation between socio-economic status of parents with learning motivation of Medicine Faculty Sam Ratulangi University class of 2013 students $p=0.444(p>0.05)$ and the correlation value is -0.062 . It can be concluded that there was no correlation between socioeconomic status of parents with students' learning motivation.
\end{abstract}

Keywords: socio-economic status, learning motivation

\begin{abstract}
Abstrak : Belajar merupakan proses yang tidak dapat dipisahkan dari kehidupan manusia,, Dorongan psikis dalam diri untuk belajar merupakan motivasi belajar. Dalam proses belajar, orangtua merupakan salah satu faktor yang memiliki peran. Penelitian ini bertujuan untuk mengetahui hubungan status sosial ekonomi orangtua dengan motivasi belajar mahasiswa. Pengambilan data melalui kuesioner. Hasil penelitian menunjukkan tidak ada hubungan antara status sosial ekonomi orangtua dengan motivasi belajar mahasiswa angkatan 2013 Fakultas Kedokteran Universitas Sam Ratulangi p=0,444 ( $>$ 0,05) dan nilai korelasi sebesar -0,062. Dapat disimpulkan bahwa tidak terdapat hubungan antara status sosial ekonomi orangtua dengan motivasi belajar mahasiswa.
\end{abstract}

Kata kunci: Status sosial ekonomi, motivasi belajar

Belajar merupakan proses yang tidak dapat dipisahkan dari kehidupan manusia. Belajar menurut pengertian tradisional adalah menambah dan mengumpulkan sejumlah pengetahuan, sedangkan menurut Notoadmojo belajar adalah usaha untuk menguasai segala sesuatu yang berguna untuk hidup. ${ }^{1}$ Namun tidak setiap individu memiliki dorongan untuk belajar yang sama besar. Dorongan untuk belajar inilah yang biasa disebut motivasi belajar. Menurut Winkel, Motivasi belajar ialah keseluruhan daya penggerak psikis di dalam diri siswa yang menimbulkan kegiatan belajar, menjamin kelangsungan kegiatan belajar dan memberikan arah pada kegiatan belajar itu demi mencapai suatu tujuan. Dengan adanya motivasi akan meningkatkan, memperkuat dan mengarahkan proses belajarnya, sehingga akan diperoleh keefektifan dalam belajar. ${ }^{2}$

Penelitian sebelumnya yang dilakukan Hamdu dan Agustina menunjukan motivasi belajar memliki pengaruh yang signifikan 
terhadap prestasi belajar, dengan tingkat pengaruh sebesar $49,1 \% .^{3}$ Hal yang senada juga disampaikan oleh Ayub, dalam penelitiannya dimana motivasi intrinsik dan ekstrinsik memiliki korelasi positif dengan pencapaian akademis $(r=.563 ; n=200$; sig= $.000){ }^{4}$

Orangtua merupakan salah satu faktor yang berperan dalam proses belajar sang anak. Orangtua yang mampu berkomunikasi dengan baik, penuh perhatian terhadap anak, tahu kebutuhan dan kesulitan yang dihadapi anak, dan mampu menciptakan hubungan baik dengan anak-anaknya akan berpengaruh besar terhadap keberhasilan belajar anak tersebut atau sebaliknya. ${ }^{1}$ Penelitian yang dilakukan Hasanah, menunjukan adanya pengaruh yang signifikan antara lingkungan keluarga dengan hasil belajar siswa. ${ }^{5}$

Menurut W.A. Gerungan ${ }^{6}$ dengan adanya perekonomian yang cukup, lingkungan material yang dihadapi anak di dalam keluarganya lebih luas, ia mendapat kesempatan yang lebih luas untuk mengembangkan bermacam-macam kecakapan yang tidak dapat ia kembangkan apabila tidak ada prasarananya.

Penelitian yang sebelumnya dilakukan oleh Dini Rahmawati, Hubungan status sosial ekonomi orangtua dengan motivasi belajar PAI siswa SMP Darussalam di Ciputat, menunjukkan terdapat korelasi yang signifikan antara status sosial ekonomi orangtua dengan motivasi belajar PAI pada siswa. Dimana siswa yang orangtuanya mempunyai status sosial ekonomi yang tinggi (memadai), maka siswa tersebut akan mempunyai motivasi belajar yang tinggi pula untuk lebih giat dalam belajar. ${ }^{7}$

Winkel mengemukakan hal yang berbeda, keadaan sosial ekonomi keluarga yang baik dapat menciptakan kondisi siswa yang menghambat dalam belajar, siswa berpikir bahwa untuk apa belajar dengan sungguh-sungguh/rajin jika semua kebutuhan sudah terpenuhi. Sebaliknya siswa yang berasal dari lingkungan keluarga yang ekonominya lemah biasanya kerap jauh lebih rajin namun ada juga siswa yang merasa minder bila belajar dengan anak-anak orang kaya. ${ }^{8}$ Hal ini juga diperkuat oleh penelitian yang dilakukan Ghaemi dan Yazdanpanah yang menunjukan adanya korelasi negatif antara status sosial ekonomi dengan prestasi belajar pada mahasiswa. ${ }^{9}$

Berdasarkan uraian masalah diatas, penulis ingin meneliti tentang hubungan status sosial ekonomi dengan motivasi belajar.

\section{METODE PENELITIAN}

Penelitian ini menggunakan metode penelitian deskriptif analitik dengan pendekatan cross sectional. Penelitian ini memiliki 2 hipotesis:

H0: tidak ada hubungan antara status sosial ekonomi orangtua dengan motivasi belajar mahasiswa.

H1: ada hubungan antara status sosial ekonomi orangtua dengan motivasi belajar mahasiswa

Penelitian dilaksanakan di Fakultas Kedokteran Universitas Sam Ratulangi Manado pada bulan Oktober hingga Desember 2014. Populasi penelitian ialah seluruh mahasiswa angkatan 2013 Fakultas Kedokteran Universitas Sam Ratulangi sejumlah 259 mahasiswa. Besar sampel ditentukan dengan menggunakan rumus Slovin dan didapatkan besar sampel sebanyak 157.

Metode pengambilan sampel yang digunakan ialah simple random sampling. Penelitian ini menggunakan kuesioner status sosial ekonomi yang terdiri dari 12 pertanyaan dengan pilihan jawaban menggunakan skala skor dan kuesioner motivasi belajar yang terdiri dari 29 pertanyaan dengan pilihan jawaban menggunakan skala likert. Pengolahan data dilakukan dengan cara: editing, coding, processing, cleaning. Analisis data menggunakan teknik analisis korelasi Spearman Rank. 


\section{HASIL PENELITIAN}

\section{Analisis Univariat}

Tabel 1 memperlihatkan bahwa hanya 1 responden (6\%) dengan status sosial ekonomi orangtua yang rendah, terbanyak 114 responden $(72,6 \%)$ dengan status sosial ekonomi orangtua yang sedang dan 42 responden $(26,8 \%)$ dengan status sosial ekonomi orangtua yang tinggi.

Berdasarkan Tabel 2 diketahui tidak ada responden yang memiliki motivasi belajar yang rendah, sebanyak 51 responden (32,5\%) memiliki motivasi belajar yang sedang dan terbanyak 106 responden (67,5\%) memiliki motivasi belajar yang tinggi.

Tabel 1. Karakteristik status sosial ekonomi orangtua

\begin{tabular}{ccc}
\hline & Responden & $\mathbf{( \% )}$ \\
\hline Rendah & 1 & $6 \%$ \\
Sedang & 114 & $72,6 \%$ \\
Tinggi & 42 & $26,8 \%$ \\
Total & 157 & $100 \%$ \\
\hline
\end{tabular}

Tabel 2. Karakteristik motivasi belajar mahasiswa

\begin{tabular}{ccc}
\hline & Responden & $(\mathbf{\% )}$ \\
\hline Sedang & 51 & $32,5 \%$ \\
Tinggi & 106 & $67,5 \%$ \\
Total & 157 & $100 \%$ \\
\hline
\end{tabular}

Tabel 3. Tabulasi silang jenis kelamin dengan motivasi belajar

\begin{tabular}{ccccc}
\hline & & \multicolumn{2}{c}{ Kategori motivasi belajar } & \multirow{2}{*}{ Total } \\
& & Sedang & Tinggi & \\
\hline \multirow{2}{*}{ Jenis Kelamin } & L & $16(35,6 \%)$ & $29(64,4) \%$ & $45(100 \%)$ \\
& $\mathbf{P}$ & $35(31,3 \%)$ & $77(68,7 \%)$ & $112(100 \%)$ \\
Total & & $51(32,5 \%)$ & $106(67,5 \%)$ & $157(100 \%)$ \\
\hline
\end{tabular}

Tabel 4. Tabulasi silang status sosial ekonomi dengan motivasi belajar

\begin{tabular}{|c|c|c|c|c|c|}
\hline & & & \multicolumn{2}{|c|}{ Kategori motivasi belajar } & \multirow{2}{*}{ Total } \\
\hline & & & Sedang & Tinggi & \\
\hline \multirow{6}{*}{$\begin{array}{l}\text { Status sosial } \\
\text { ekonomi }\end{array}$} & \multirow{2}{*}{ Rendah } & Count & $0(0 \%)$ & $1(100 \%)$ & 1 \\
\hline & & $\%$ Total & $0 \%$ & $0,6 \%$ & $0,6 \%$ \\
\hline & \multirow{2}{*}{ Sedang } & Count & $35(30,7 \%)$ & $79(69,3 \%)$ & 114 \\
\hline & & \%Total & $22,3 \%$ & $50,3 \%$ & $72,6 \%$ \\
\hline & \multirow[t]{2}{*}{ Tinggi } & Count & $16(38,1 \%)$ & $26(61,9 \%)$ & 42 \\
\hline & & \%Total & $10,2 \%$ & $16,6 \%$ & $26,8 \%$ \\
\hline Total & & Count & $51(32,5 \%)$ & $106(67,5 \%)$ & $157(100 \%)$ \\
\hline
\end{tabular}


Pada Tabel 3 diketahui dari 45 reponden laki-laki, 16 orang $(35,6 \%)$ diantaranya memiliki motivasi belajar yang sedang dan 29 orang $(64,4 \%)$ memiliki motivasi belajar yang tinggi. Sedangkan untuk 112 responden perempuan, 35 orang (31,3\%) diantaranya memiliki motivasi belajar yang sedang dan yang tertinggi sebanyak 77 orang (72,6\%) memiliki motivasi belajar yang tinggi.

Pada tabulasi silang dalam Tabel 4 dapat dilihat bahwa responden tersedikit yaitu yang berada pada status sosial ekonomi rendah hanya 1 orang (100\%) responden memiliki motivasi belajar yang tinggi; pada status sosial ekonomi yang sedang, 35 orang (30,7\%) responden memiliki motivasi belajar sedang dan yang terbanyak sebanyak 79 orang $(69,3 \%)$ responden memiliki motivasi belajar yang tinggi, dan pada status sosial ekonomi yang tinggi, 16 orang $(38,1 \%)$ responden memiliki motivasi belajar yang sedang dan 26 orang $(61,9 \%)$ responden memiliki motivasi belajar yang tinggi.

\section{Analisis bivariat}

Berdasarkan hasil uji statistik Spearman's rank pada Tabel 5, diketahui nilai koefisien korelasi yang dihasilkan sebesar 0,062 yang berdasarkan kriteria pedoman koefisien korelasi berada pada rentang 0,00-0,199 yang berarti sangat rendah hingga secara statistik dianggap tidak ada korelasi antara status sosial ekonomi orangtua dengan motivasi belajar mahasiswa. Tanda negatif menunjukkan arah hubungan korelasi, yaitu status sosial ekonomi orangtua berbanding terbalik dengan motivasi belajar mahasiswa.

Berdasarkan analisis data diketahui nilai signifikansi $0,444>0,05$ sehingga hipotesis H0 diterima dan H1 ditolak, artinya tidak terdapat hubungan antara status sosial ekonomi orangtua dengan motivasi belajar mahasiswa.

\section{BAHASAN}

Analisis dalam penelitian ini didapatkan hasil nilai sig. $=0,444>0,05$. Dengan demikian H1 ditolak dan secara otomatis hipotesis yang diterima yaitu H0 dimana tidak terdapat hubungan antara status sosial ekonomi orangtua dengan motivasi belajar mahasiswa. Tidak adanya korelasi ini diperkuat oleh penelitian yang dilakukan Young A, Johnson G, Arthur H \& Hawthorne M (2011) dengan judul Cultural and socioeconomic differences in academic motivation and a selfdeterministic approach, dimana dalam penelitiannya dilaporkan bahwa budaya (culture) dan status sosial ekonomi memiliki peran dalam pencapaian akademik dan motivasi akademik, namun tidak menemukan bukti yang cukup untuk menunjukan bahwa hanya status sosial ekonomi dapat mempengaruhi motivasi namun didapatkan tingginya nilai untuk motivasi eksternal yang mungkin diindikasikan dengan status sosial ekonomi. ${ }^{10}$

Berbeda dengan penelitian yang di lakukan oleh Dini Rahmawati dengan judul hubungan status sosial ekonomi orangtua dengan motivasi belajar PAI siswa SMP Darussalam di Ciputat, dengan nilai $\mathrm{r}=$ 0,64 menunjukkan terdapat korelasi yang signifikan antara status sosial ekonomi orangtua dengan motivasi belajar PAI pada siswa. Dimana siswa yang orangtuanya mempunyai status sosial ekonomi yang tinggi (memadai), maka siswa tersebut akan mempunyai motivasi belajar yang tinggi pula untuk lebih giat dalam belajar. Namun dalam penelitian dini hanya memiliki koefisien determinasi sebesar $40,9 \%$ dimana variabel status sosial ekonomi orangtua hanya memberikan kontribusi sebesar 40,9\% terhadap motivasi belajar siswa, dan sisanya sebesar 59,1\% dipengaruhi oleh faktor-faktor lain, yang menunjukkan faktor sosial ekonomi orangtua tidak sampai 50\% memiliki peran dalam motivasi belajar pada siswa, dan lebih dari $50 \%$ dipengaruhi oleh faktorfaktor lain.

Perbedaan hasil penelitian ini dengan 
penelitian yang dilakukan oleh Dini $\mathrm{R}$ mungkin terletak pada subyek penelitian; penelitian ini mengambil sampel mahasiswa di bangku universitas sedangkan penelitian yang dilakukan oleh Dini R mengambil sampel siswa bangku SMP. Penelitian yang dilakukan oleh Caroline Mansfield dan Marold Wosnitza dengan judul Motivation goals during adolescence: a cross sectional perspective yang menbahas perspektif tujuan dari motivasi remaja dalam konteks belajar. Penelitian ini menunjukan terdapat perbedaan antara tujuan dari motivasi belajar dimana siswa golongan remaja awal memiliki skor tujuan pencapaian akademik (achievement goal) lebih tinggi dibandingkan dengan remaja akhir. ${ }^{11}$

Diketahui distribusi responden berdasarkan jenis kelamin memiliki selisih yang cukup besar antara jenis kelamin laki - laki dan perempuan, yaitu 45 reponden (28,7\%) berjenis kelamin laki-laki dan terbanyak 112 responden (71,3\%) berjenis kelamin perempuan. Perbedaan yang cukup jauh ini disebabkan memang sedikitnya jumlah laki-laki di angkatan 2013, yang hanya 80 orang dibandingkan dengan perempuan yang jumlahnya 179 orang. Dalam tabulasi silang dapat dilihat baik responden laki-laki maupun perempuan keduanya masing-masing lebih dari 50\% respondennya memiliki motivasi belajar yang tinggi; dengan responden perempuan $68,8 \%$ nya memiliki motivasi belajar yang tinggi dan laki-laki sebanyak 64,4\%.

Perbedaan signifikan jumlah responden laki-laki dan perempuan ini juga dapat dianggap memiliki pengaruh terhadap hasil penelitian. Brouse dkk dalam penelitiannya College students' academic motivation: differences by gender, classs and source of payment melapokan bahwa perempuan memiliki level motivasi yang tinggi dibandingkan laki-laki baik dalam ekstrinsik maupun intrinsik, ${ }^{12}$ sedangkan Nadia Ayub dalam penelitiannya Effect of Intrinsic and Extrinsic motivation on academic performance mendapatkan hasil adanya perbedaan variabel motivasi intrinsik dan ekstrinsik antara laki-laki dan perempuan, dimana perempuan lebih termotivasi secara intrinsik dibandingkan laki-laki, dan sebaliknya laki-laki lebih termotivasi secara ekstrinsik dibandingkan perempuan. $^{4}$ Mungkin hal ini yang menyebabkan perempuan sebagai responden terbanyak dengan motivasi yang tinggi namun lebih termotivasi secara intrinsik, dimana motivasi intrinsik adalah motif-motif yang menjadi aktif atau berfungsinya tidak perlu dirangsang dari luar, sedangkan motivasi ekstrinsik apabila seseorang menempatkan tujuan belajarnya diluar faktor-faktor situasi belajar. Misalnya untuk mencapai angka tinggi, diploma, gelar, kehormatan dan sebagainya. ${ }^{13}$

Tanda negatif pada koefisien korelasi $\mathrm{r}$ $=-0,062$ menunjukkan arah hubungan korelasi, yaitu status sosial ekonomi orangtua berbanding terbalik dengan motivasi belajar mahasiswa, yang berarti makin rendahnya status sosial ekonomi diikuti peningkatan motivasi belajar. Hal ini mungkin disebabkan oleh banyaknya responden yang berasal dari status sosial ekonomi yang sedang dibandingkan sosial ekonomi yang tinggi dan rendah. Dapat dilihat dalam tabel tabulasi silang antara status sosial ekonomi dengan motivasi belajar, dimana dari 114 responden dengan status sosial ekonomi sedang, 79 orang (69,3\%) respondennya memiliki motivasi belajar yang tinggi. Ditunjukkan pula bahwa 50,3\% dari total responden berada pada status sosial ekonomi sedang dengan motivasi belajar yang tinggi. Selain itu satu-satunya responden yang berada pada status sosial ekonomi rendah pun memiliki motivasi belajar yang tinggi.

Tidak ditemukannya hubungan $\left(\mathrm{r}_{\mathrm{s}}=\right.$ 0,062, $\mathrm{p}=0,444>0,05)$ dalam penelitian ini menunjukkan bahwa status sosial ekonomi orangtua mahasiswa angkatan 2013 fakultas kedokteran manado tidak memiliki hubungan terhadap motivasi belajar mahasiswa. Hal ini mungkin 
disebabkan karena adanya faktor-faktor lain yang lebih berperan terhadap motivasi belajar mahasiswa. Rivka dalam penelitiannya, Faktor-faktor yang mempengaruhi motivasi belajar demi mencapai performance akademik yang baik di kalangan mahasiswa, menyebutkan banyak faktor-faktor yang mempengaruhi motivasi belajar mahasiswa, antara lain yaitu: Faktor individual yang terdiri dari latihan, motivasi, faktor pribadi, nonintelektual, keinginan siswa untuk belajar; Faktor sosial yang terdiri dari pola asuh keluarga, guru dan cara pengajarannya, alat yang dipakai, kesempatan, spiritual \& komunikasi; dan tugas perkembangan masa dewasa muda yaitu pekerjaan dan rumah tangga. ${ }^{14}$

\section{SIMPULAN}

Berdasarkan hasil penelitian dapat disimpulkan bahwa tidak terdapat hubungan antara status sosial ekonomi orangtua dengan motivasi belajar pada mahasiswa angkatan 2013 Fakultas Kedokteran Universitas Sam Ratulangi dengan nilai $r_{\mathrm{s}}=-0,062$ dan sig. $=0,444>$ 0,05 .

\section{SARAN}

1. Bagi orangtua dan institusi diharapkan dapat memperhatikan faktor-faktor lain yang mungkin memiliki hubungan dan dapat meningkatkan motivasi belajar mahasiswa,

2. Bagi mahasiswa diharapkan dapat tetap mempertahankan motivasi belajar yang tinggi,

3. Bagi peneliti selanjutnya diharapkan dapat melihat dan mengukur variabel lain yang berhubungan dengan motivasi belajar dan menyempurnakan penelitian yang telah ada.

\section{DAFTAR PUSTAKA}

1. Sunaryo. Psikologi untuk keperawatan. Jakarta: Penerbit buku kedokteran EGC, 2004

2. L. Vivi. Peningkatan motivasi belajar IPS siswa kelas VIII dengan menggunakan metode snowball throwing di SMPN 4 satu atap bawang Banjarnegara [skripsi S1]. Yogyakarta: Universitas Negeri Yogyakarta; 2012

3. Hamdu G, Agustina L. Pengaruh motivasi belajar siswa terhadap prestasi belajar IPA di sekolah dasar. Jurnal Penelitian Pendidikan. Pendidikan [serial online]. 2011 [cited 2014 Oct 11]. Available from: http://jurnal.upi.edu/file/8Ghullam_Hamdu.pdf

4. Ayub N. Effect of intrinsic and extrinsic motivation of academic performance. Pakistan Business Review [serial on the internet]. 2010 [cited 2014 Oct 12] Available

from:http://www.iobm.edu.pk/PBR/10 07/PBR_1007_363_The\%20Effect\%20 of\%20Inrinsic\%20and\%20Extrinsic\%2 0Motivation\%20revise.pdf

5. Hasanah B. Pengaruh lingkungan keluarga terhadap hasil belajar siswa pada mata pelajaran geografi di SMA negeri 1 Marawola. E-Journal Geo-Tadulako UNTAD [serial online]. 2014 [cited 2014 Oct 12];2(3):1-13. Available from:

http://jurnal.untad.ac.id/jurnal/index.ph p/GeoTadulako/article/view/2609

6. Gerungan W. A. Psikologi Sosial. Bandung: Refika Aditama, 2010

7. Rahmawati D. Hubungan status social ekonomi orangtua dengan motivasi belajar PAI siswa di SMP Darussalam Ciputat. [skripsi S1]. Jakarta: Universitas Islam Negeri Syarif Hidayatullah; 2010

8. Widjdati Y. Pengaruh status sosial ekonomi orangtua terhadap prestasi belajar siswa. Jurnal Ilmiah Pendidikan Geografi [serial online]. 2013 [cited 2014 Oct 05];1(2):99-111. Available from:

http://download.portalgaruda.org/articl e.php?article $=251593 \& v a l=6772 \&$ title =Pengaruh\%20Status\%20Sosial\%20Ek onomi\%20Orang\%20Tua\%20Terhadap \%20Prestasi\%20Belajar\%20Siswa

9. Ghaemi F, Yazdanpanah $\mathbf{M}$. The relationship between socio-economic status and academic achievement in the efl classroom among iranian university students. European Journal of English Language and Literature Studies 
2014;2(1):49-57

10. Young A, Johnson G, Arthur $H$ \& Hawthorne M. Cultural and socioeconomic differences in academic motivation and a self-deterministic approach. Journal of Border Educational Research [serial online]. 2011 [cited 2014 Dec 20];9:37-46. Available from: http://www.researchgate.net/publicatio n/260970420_Cultural_predictors_of_a cademic_motivation_and_achievement _A_self-deterministic_approach

11. Mansfield C. \& Wosnitza M. Motivation goals during adolescence: a cross sectional perspective. Issues in Educationl Research [serial online]. 2010 [cited 2014 Dec 20]; 20(2):14965. Available http://www.iier.org.au/iier20/mansfield .pdf

12. Brouse. College students' academic motivation: differences by gender, classs and source of payment. College Quarterly.[serial on the internet] 2010 [cited 2015 Jan 04]; 13(1). Available from:

http://www.collegequarterly.ca/2010vol13-num01-winter/brouse-baschleblanc-mcknight-lei.html

13. Islamuddin H. Psikologi Pendidikan. Yogyakarta: Pustaka Pelajar, 2012.

14. Rustanto R. Faktor-faktor yang mempengaruhi motivsi belajar demi mencapai performance akademik yang baik di kalangan mahasiswa.[skripsi S1]. Semarang: Universitas Katolik Soegijapranata; 2 